\title{
Innovative Reuse of Electric Arc Furnace Slag as Filler for Different Polymer Matrixes
}

\author{
Anna Gobetti ${ }^{1, *}$, Giovanna Cornacchia ${ }^{2} \mathbb{C}$ and Giorgio Ramorino ${ }^{1}$ \\ 1 Materials Science and Technology at Department of Mechanical and Industrial Engineering, \\ University of Brescia, 25123 Brescia, Italy; giorgio.ramorino@unibs.it \\ 2 Metallurgy at Department of Mechanical and Industrial Engineering, University of Brescia, \\ 25123 Brescia, Italy; giovanna.cornacchia@unibs.it \\ * Correspondence: a.gobetti@unibs.it
}

Citation: Gobetti, A.; Cornacchia, G.; Ramorino, G. Innovative Reuse of Electric Arc Furnace Slag as Filler for Different Polymer Matrixes. Minerals 2021, 11, 832. https://doi.org/ $10.3390 / \min 11080832$

\section{Academic Editor:}

Alexander Mikhailovich Kalinkin

Received: 14 June 2021

Accepted: 28 July 2021

Published: 30 July 2021

Publisher's Note: MDPI stays neutral with regard to jurisdictional claims in published maps and institutional affiliations.

Copyright: (c) 2021 by the authors. Licensee MDPI, Basel, Switzerland. This article is an open access article distributed under the terms and conditions of the Creative Commons Attribution (CC BY) license (https:// creativecommons.org/licenses/by/ $4.0 /)$.

\begin{abstract}
The European steel industry produces about 70 million tons/year of steel by the electric arc furnace (EAF). The slag consists of about $15 \%$ by weight of the produced steel, thus from the perspective of the circular economy, it has a high potential as a co-product. This research aims to assess an innovative reuse of EAF slag as filler in different polymer matrixes: thermoplastic (polypropylene), thermosetting (epoxy resin), elastomeric (nitrile butadiene rubber), and recycled end of life rubber tire. A comparison between neat polymer and polymer filled with a certain amount of EAF slag has been carried out by tensile (or flexural), compression, and hardness tests. Experimental results show that slag as a filler increases the composites' hardness and elastic modulus at the expense of toughness. For a safe reuse of the slag, the leaching of hazardous elements must comply with current legislation. It was found that, although the used EAF slag releases small amounts of $\mathrm{Cr}, \mathrm{Mo}$, and $\mathrm{V}$, incorporating it into a polymer matrix reduces the leaching. The EAF slag particles distribution has been observed by scanning electron microscopy (SEM) images. The obtained results show good technical feasibility of this innovative slag application so that it could pave the way to a new industrial symbiosis between dissimilar sectors, bringing economic and environmental benefits.
\end{abstract}

Keywords: EAF slag reuse; epoxy matrix; NBR matrix; end of life rubber tire; PP matrix; tensile test; flexural test; compression test; hardness test; leaching test

\section{Introduction}

The attention of manufacturing industries in recent years has increasingly focused on the implementation of systems aimed at improving the recycling rate of by-products and the valorization of waste as an environmentally and economically advantageous alternative to the ever-increasing disposal costs. This is due to the increasing sensitivity towards the preservation of natural resources and the big problem of waste disposal that led the EU Commission to issue Directive 2008/98 [1] and the ambitious goal of "zero waste" [2].

In this context, the European steel industry produces about 70 milion tons/year of steel by the electric arc furnace (EAF) and Italy is the leading producer, with a production of about 20 million tons/year of EAF steel [3].

Slag is the by-product produced in the greatest quantity and it is functional to the production of the metal itself. In addition to its main function of absorbing deoxidizing products and impurities from molten steel, EAF slag performs other functions: it protects the electrodes and refractories in the furnace from arc irradiation, protects the molten steel from reoxidation, and acts as a thermal insulator to prevent heat dispersion into the surrounding environment. This allows to increase the thermal efficiency in EAF by controlling the heating speed of the furnace, and by maximizing the active power of the transformer improving electrical stability [4].

During the steel production processes, dust and sludge are also produced but the slag is the main scrap, representing more than $90 \%$ by mass of all by-products. Since the slag 
consists of about $15 \%$ by weight of the produced steel, Italy produces about 2.5 million tons of slag every year [5]. From the perspective of the circular economy, slag has a high potential as a co-product.

It should be emphasized that the enhancement of by-products aims both at their use in the production of conventional artefacts and at the study and development of new products. Through a new destination of waste materials, large quantities of them will be saved from landfills and the extraction of raw material will be reduced.

Currently, steel slags can be recycled for internal metallurgical purposes [6] or used in road construction [7] cement and concrete [8-13], bituminous mixes [14], fertilizer [6], and soil improvement [15]. Despite this, a large amount of slag is not used today.

The knowledge of the chemical and physical characteristics is fundamental to in-crease the reuse of the slag both internally and in different fields of application. In particular, the knowledge of the composition of the various phases allows the development of ad hoc stabilization methods making the slag suitable for its reuse [16-19]. EAF slag is named also "black" slag when it is derived by the smelting of the scrap metals, while it is known as "white" slag when it is derived by the following refining process in the ladle, out-side the furnace. One of the main critical aspects of the use of steel slag is the leaching behavior, i.e., the release of substances harmful to the environment and humans [20].

The chemical composition of EAF slag depends significantly on the properties of the recycled steel and it is strongly influenced by the production process. EAF slags mainly consist of $\mathrm{FeO}(10-40 \%), \mathrm{CaO}(22-60 \%), \mathrm{SiO}_{2}(6-34 \%), \mathrm{Al}_{2} \mathrm{O}_{3}(3-14 \%), \mathrm{MgO}(13-14 \%)$ and other minor oxides [21]. EAF slags also contain free $\mathrm{CaO}$ and $\mathrm{MgO}$ along with other complex minerals and solid solutions of $\mathrm{CaO}, \mathrm{FeO}$, and $\mathrm{MgO}$ [22]. $\mathrm{Ca}$ and $\mathrm{Si}$ come from the materials added to the liquid steel bath, $\mathrm{Mg}$ is related to the attack of the steel bath on the refractory brick of the furnace, and the presence of other elements such as $\mathrm{Cr}, \mathrm{Ti}, \mathrm{Cu}$ derived from the impurities contained in the ferrous scrap [23].

For safe reuse of EAF slag, its characteristics must comply with specified limits, this means not only that slag chemical composition must fall within specified ranges, but also that the leaching of environmentally harmful or undesired elements (including $\mathrm{Cr}, \mathrm{Mo}$, and V) into the environment must be kept under strict control. The possible release of heavy metals must be checked by the leaching test according to the standard CEN EN 12457 "Characterisation of waste-Leaching-Compliance test for leaching of granular waste materials and sludges". The differences in the results are due to the intrinsic heterogeneity of the slags, which is high even if the slag from the same casting is considered [20].

It should be noted that the CEN EN12457 standard is divided into 4 parts that differ in the strictness of the test conditions and there is no homogeneity in its interpretation. In fact, several European countries adopt different parts of the standard [24-27]. In particular the differences in the test conditions consist of different sample particle sizes, liquid/solid ratio and stirring time. Denmark adopts the most restrictive part of the standard: CEN EN 12457-1 [24], Italy and Germany adopt CEN EN 12457-2 [25], while most of European countries (France, Spain, et al.) adopt the most permissive CEN EN 12457-4 [27,28]. Concerning the Italian regulation, the government issued the Ministerial decree 5 April 2006 [29] for material reuse and Ministerial Decree 3 August 2005 [30] for landfill disposal. Both of them impose different threshold limits of several elements leaching (measured according to the standard CEN EN 12457-2 [25]).

This research aims to assess the influence of EAF slag in different polymer matrixes: thermoplastic (polypropylene (PP)), thermosetting (epoxy resin), elastomeric (nitrile butadiene rubber (NBR)), and recycled end of life rubber tire (ELT).

The reuse of EAF slag as filler for a polymer matrix was assessed for the first time in 2015 by Cornacchia et al. [31]. Nevertheless, it is interesting to evaluate the influence of EAF slag also in materials which belong to a very different class of polymers characterized by different applications, production process and behavior. 
Thermoplastics are formed by linear or slightly branched chains, not linked to each other. Their production process consists of compounding the polymer and the fillers by extrusion process, then the products are manufactured mainly via injection molding or extrusion process.

Thermosets are cross-linked polymers, with higher degree of cross-linking than elastomers, so the crosslinks hinder the mobility of the macromolecules, giving rise to rigid material.

Elastomers could be either thermoplastic or thermosetting, but the present research will focus on thermosetting elastomers. They are produced by linking polymer chains to each other by chemical reactants, temperature, and pressure in a process generally called vulcanization.

Rubber tires are thermosetting elastomers, and due to the huge amount of end of life rubber tires (approximately 3 billion tires/year worldwide [32]) their management is a major concern [33].

In a context that is increasingly pushing towards a circular economy model, the reuse and recovery of waste is fundamental. The purpose of this research is to promote the reuse of EAF slag in different polymer matrixes not principally as a performing filler but as sustainable filler that brings economic and environmental benefits in a circular economy prospective. The cited polymers filled with EAF slag are distinguished by different benefit. The addition of EAF slag to NBR, for applications where the requirements are high hardness and stiffness, could represent an alternative to high carbon black filled NBR. As car-bon black derives from hard coal tar, replacing it with a waste material results in the double environmental benefit: reduce slag landfilling and carbon black production. Carbon black replacement has been studied in other studies [34-37], however this is the first time it is replaced by a waste derived by the steel industry. Regarding epoxy matrix for some applications, it is filled with quartz or silica [38,39]. EAF slag could represent an alternative filler in order to preserve the exploitation of natural resources. Finally, the use of EAF slag as filler for ELT matrix allows to improve some mechanical properties of a recycled material without employing any virgin raw material. This results in a $100 \%$ recycled composite material.

The economic advantages deriving from the use of slag as a filler must be evaluated in terms of:

Cost of the raw material: steel producers are willing to provide the slag free of charge as this would save them from incurring disposal costs;

Cost of process crushing the slag into fine powder. The energy costs for the slag crushing and grinding have been evaluated a function of the slag hardness in [40]. Petrík et al. [41] studied hardness test conditions for micro-hardness testing.

\section{Materials and Methods}

\subsection{Materials and Compounds Preparation}

\subsubsection{Filler: EAF Slag}

The slag employed in this research as filler has been produced by an electric arc furnace process, so that it is a "black" slag. In particular after slagging it has been treated by a specific system named Slag-Rec $[17,31]$.

In traditional processes the slag is discontinuously discharged from electric-arc furnaces and it is left to cool down to room temperature. This leads to two main issues: (i) solidification occurs in in block and the slag needs to be crushed in loco for handling; (ii) the slag cooling rate is not taken under control, although it is the main parameter to be considered to lowering the solubility of the heavy metals [42,43].

The Slag-Rec system is a process designed to manage the slag as a co-product allowing to solve mentioned issues. After slugging, the slag is rapidly cooled as it passes between two water-cooled cylinders to form a thin plate that is easy to crush.

Nevertheless, the use of EAF slag as filler is not to be considered bound to it. 
EAF slag has been ground by a manual pulverizing mill HSM 100 provided by Herzog (Osnabrück, Germany) for a grinding time of $25 \mathrm{~s}$ and then it has been sieved by the sieve number 140 (ASTM E11-20 [44]) to obtain a grain size $<106 \mu \mathrm{m}$.

EAF slag used as filler for PP matrix in [31] was produced by the same Slag-Rec system, but it derived from a different casting with respect to that used as filler for NBR, ELT, and epoxy matrixes.

\subsubsection{Polypropylene (PP)}

Commercially available polypropylene homopolymer (ECOLEN HZ10D; Hellenic Petroleum, Athens, Greece) was supplied by Industrie Generali Spa (Quattro Strade, Milan, Italy). Following some key parameters of this PP are reported: melt flow rate $=1.8 \mathrm{~g} / 10 \mathrm{~min}$ $\left(230{ }^{\circ} \mathrm{C} / 2.16 \mathrm{~kg}\right)$ and density $=0.9 \mathrm{~g} / \mathrm{cm}^{3}$. The melting point of commercial PP is about $160{ }^{\circ} \mathrm{C}$ to $170{ }^{\circ} \mathrm{C}$.

Before blending EAF slag as filler for PP matrix, the powder was dried in a vacuum oven at $85{ }^{\circ} \mathrm{C}$ for about 2 days to eliminate moisture. Composite with $30 \mathrm{wt} . \%$ of EAF slag was prepared by using a co-rotating twin-screw extruder at a barrel temperature of $185-200{ }^{\circ} \mathrm{C}$, and a screw speed of $15.7 \mathrm{rad} / \mathrm{s}(150 \mathrm{rpm})$. During melt extrusion, the ventilation was kept on removing trapped air in compounds. After extrusion, the composite was solidified by passing it through a water bath and finally pelletized. As a reference, neat PP was processed similarly to ensure analogous process conditions and thermomechanical history. Dumb-bell-shaped specimens were produced for the tensile test (ISO 527-1:2012 [45]). PP characteristics and PP composite production details are described in [31].

\subsubsection{Epoxy Resin}

The thermosetting matrix consists of epoxy resin E-227 provided by Prochima Srl (Colli Al Metauro, Pesaro and Urbino, Italy). This is a class of reactive pre-polymers and polymers characterized by the presence of epoxide groups. The bi-component product is formed by polymer and catalyst that must be mixed to obtain the final product.

The preparation of the composite material samples filled with EAF slag at $60 \mathrm{wt} . \%$ $(30.3 \% v / v)$ and $80 \mathrm{wt} . \%(53.7 \% v / v)$, included the following steps: mixing manually the filler with the epoxy resin (100:50), draining the mixture in a mold, maintaining for $24 \mathrm{~h}$ at room temperature to allow the polymerization, and demolding of samples. Specimens with two different geometries were produced: one for mechanical flexural characterization (according to the standard ISO 178:2019 [46]) and one for mechanical compression characterization (according to the standard ISO 14544:2016 [47]).

\subsubsection{Nitrile Butadiene Rubber (NBR)}

Nitrile butadiene rubber (NBR) nominal hardness 70 Shore A (carbon black $40 \mathrm{phr}$, vulcanized with sulfur) provided by Novotema Spa (Villongo, Bergamo, Italy) was used as a polymeric matrix. A composite material filled with $20 \% v / v(43.9 \mathrm{wt} . \%)$ of EAF slag was compounded. The compounding process has been performed to disperse the filler particles in the NBR matrix by calendering process. The calendering process consists in forcing rubber and slag between two rotating cylinders (diameter of $150 \mathrm{~mm}$ ) $0.1 \mathrm{~mm}$ apart at room temperature. The used calender machine has been provided by Meccaniche Moderne srl (Busto Arsizio, Varese, Italy) In the calendering process, the rubber is worked in several steps during which the temperature increases $\left(70-80^{\circ} \mathrm{C}\right)$ due to the high shear stresses generated by the cylinder in the material that becomes soft. The compounds are then compression molded for $15 \mathrm{~min}$ at $180^{\circ} \mathrm{C}$ at $40 \mathrm{MPa}$ to obtain test plates $200 \mathrm{~mm} \times 200 \mathrm{~mm} \times 2 \mathrm{~mm}$ and $100 \mathrm{~mm} \times 60 \mathrm{~mm} \times 6 \mathrm{~mm}$ from which samples for the tensile test (ISO 37:2017 type 2 [48]) and compression test, respectively, are obtained by mechanical punching. 


\subsubsection{End of Life Tires (ELT)}

The rubber powder used was supplied by the Ges-Tyre Scrl consortium (Brescia, Italy). The rubber supplied derives from the industrial granulation process with an average particle size of $0.5 \mathrm{~mm}$. This material was then sieved in the laboratory in order to segregate the particle size lower than $0.5 \mathrm{~mm}$. Known the density of ELT from previous tests equal to $1.13 \mathrm{~g} / \mathrm{cm}^{3}$, the quantity of rubber powder and EAF slag to be compounded to obtain a composite material filled at $20 \% v / v(46 \mathrm{wt} . \%)$ has been determined.

The compounding process has been carried out as first to transform the ELT powder into a single and workable compound (Figure 1) thanks to a partial mechanical devulcanization, and secondly to distribute and disperse the slag particles inside this compound.
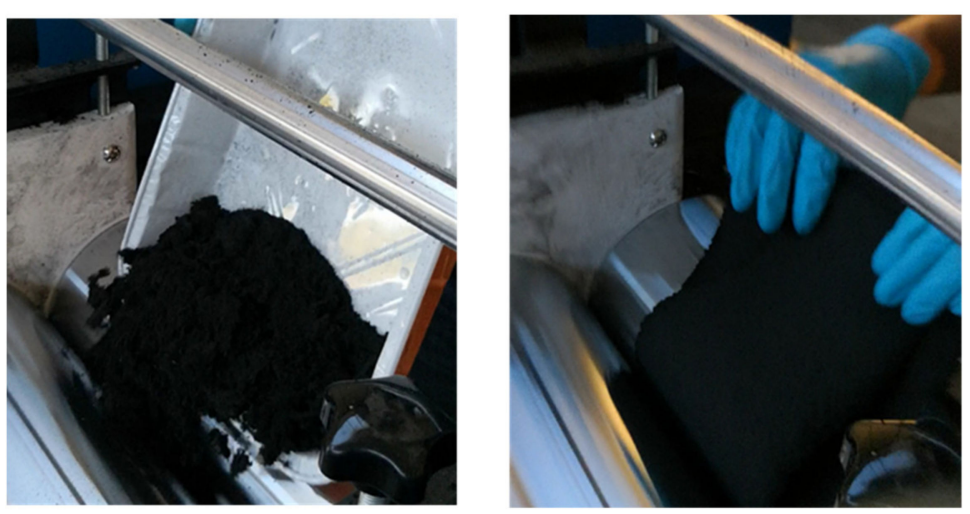

Figure 1. During the calendering process ELT powder (beginning of the process) is transformed into a compound (end of the process, after about $1 \mathrm{~h}$ ).

The calendering process consists in forcing rubber and slag between two rotating cylinders (diameter of $150 \mathrm{~mm}$ ) $0.1 \mathrm{~mm}$ apart at room temperature. The used calender machine model GAG-R905 has been provided by Gaoge-tech instrument (Dongguan, China).

In the calendering process, the rubber is worked in several steps, with a total working time of about $1 \mathrm{~h}$, during which the temperature increases up to $70-80{ }^{\circ} \mathrm{C}$ due to the high shear stresses generated by the cylinder in the material that becomes soft and plasticized.

\subsection{Methods}

\subsubsection{EAF Slag Characterization}

EAF slag chemical composition is determined by $\mathrm{X}$-ray fluorescence spectroscopy carried out by the ARL ${ }^{\mathrm{TM}}$ PERFORM'X provided by Thermo Scientific ${ }^{\mathrm{TM}}$ (Waltham, MA, United States).

EAF slag leaching of $\mathrm{Mo}, \mathrm{Cr}, \mathrm{V}, \mathrm{Cu}, \mathrm{Cd}$, and As is determined by the leaching test according to the standard CEN EN 12457-2 [25]. The tests were performed on material with particle size less than $4 \mathrm{~mm}$ according to the standard CEN EN 12457-2 [25]. Since the material had a grain size larger than $4 \mathrm{~mm}$, the entire oversized fraction was ground with the foresight not to finely grind the material.

For the EAF slag utilized as filler for epoxy resin, NBR and ELT four eluates were prepared as described above and analyzed by a Avio 200 ICP Optical Emission Spectrometer provided by Perkin Elmer (Milano, Italy). As regarding the EAF slag used in PP matrix, the leaching test has been performed on fine slag (less than $100 \mu \mathrm{m}$ ) due to the lack of material of greater grain size. It is important to highlight that this grain size results in a more severe test condition. According to literature studies [20,49-51], reducing the slag particle size causes an increase in the heavy metals leaching.

The EAF slag used as filler for PP matrix and that used for the other matrixes are obtained by the same production process but they belong to different casting, so that they could present a slightly different behavior. 


\subsubsection{Compound Characterization}

Leaching Test

To better understand the slag behavior in polymer matrices, the leaching test has been also conducted on composite materials with the following slag contents: NBR 30\% v/v (57 wt.\%), ELT 20\% v/v (46 wt.\%), epoxy resin 35.3\% v/v (65 wt.\%) and 62.1\% v/v (85 wt. \%).

As regards the leaching test of PP filled with EAF, the leaching test has been conducted on the PP composite filled with EAF slag $30 \mathrm{wt} . \%(9 \% v / v)$. Since the EAF slag used as filler for PP matrix derived from a different casting with respect to that used for the others polymer matrixes, a separate leaching test has been performed. Each slag has been tested twice.

In order to verify the contribute of non-slag materials to the leaching of $\mathrm{Cr}, \mathrm{V}$, and Mo the test has been performed also on the ELT powder. Since tested PP, NBR, and epoxy resin were virgin materials and the above mentioned elements are not present in the recipe, it is possible to state their contribute is zero. Even in the rubber used for tire production these elements are not present, anyway since ELT are recycled materials that have been used and may have been polluted, its contribution on the leaching of $\mathrm{Cr}, \mathrm{V}$, and Mo has been assessed.

The composite materials were cut (for elastomer matrixes) or crushed (for epoxy matrix) into a particle size of less than $4 \mathrm{~mm}$. The slag dust lost from the cutting surface was removed to allow the evaluation of the inertizing effect of the polymer matrix. For PP composite the leaching test was performed on the compound obtained by the extrusion process in the form of granules in a size lower than $4 \mathrm{~mm}$. The amount of composite tested was calculated in order to maintain the quantity of slag in a ratio of 1:10 with the liquid as for the characterization of free slag according to the standard EN 12457-2 [25]. The leachates have been analyzed by a Avio 200 ICP Optical Emission Spectrometer provided by Perkin Elmer (Milano, Italy) to measure the concentration in the solution of the most critical elements such as $\mathrm{Cr}$, Mo, and V (Figure 2). Each test has been performed twice.

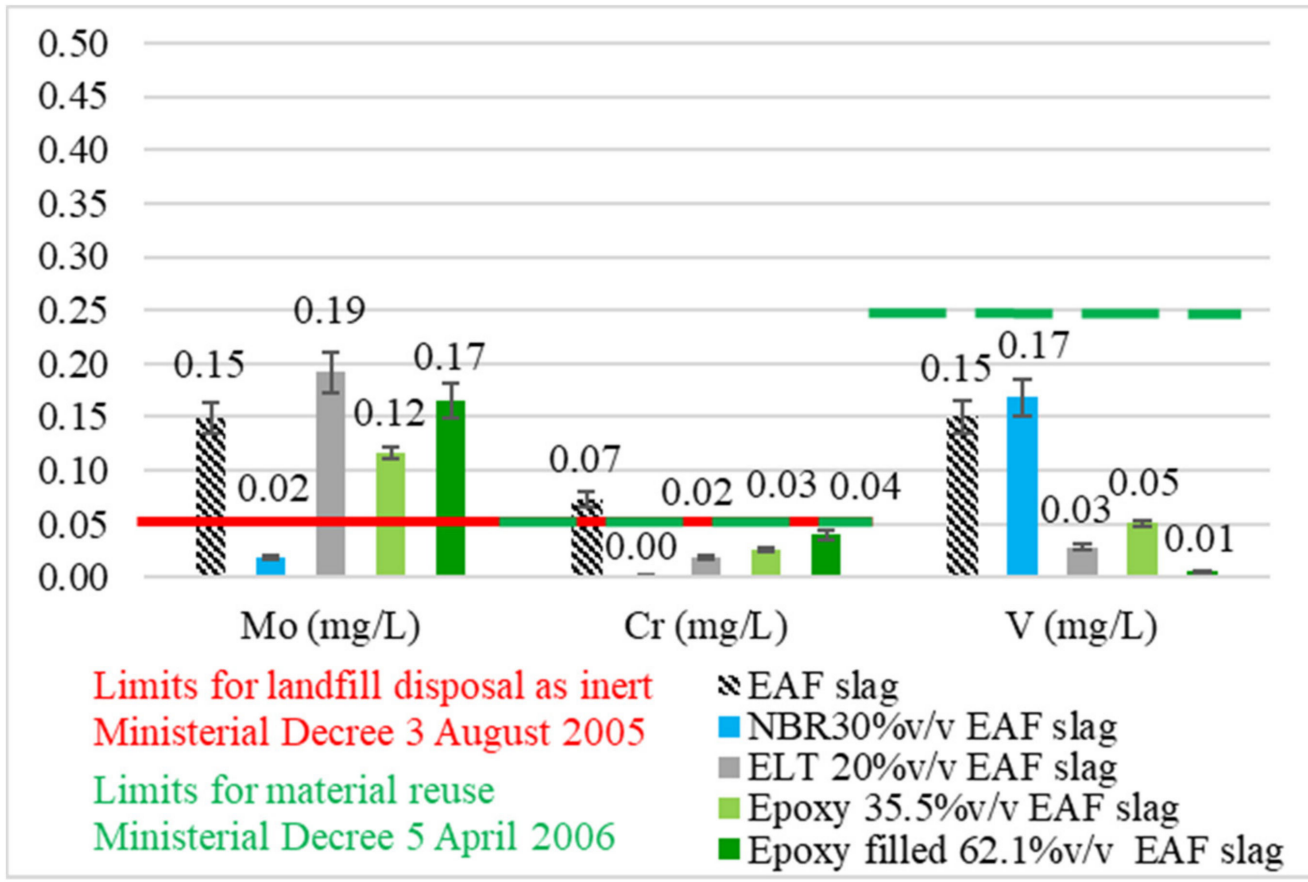

Figure 2. Cont. 


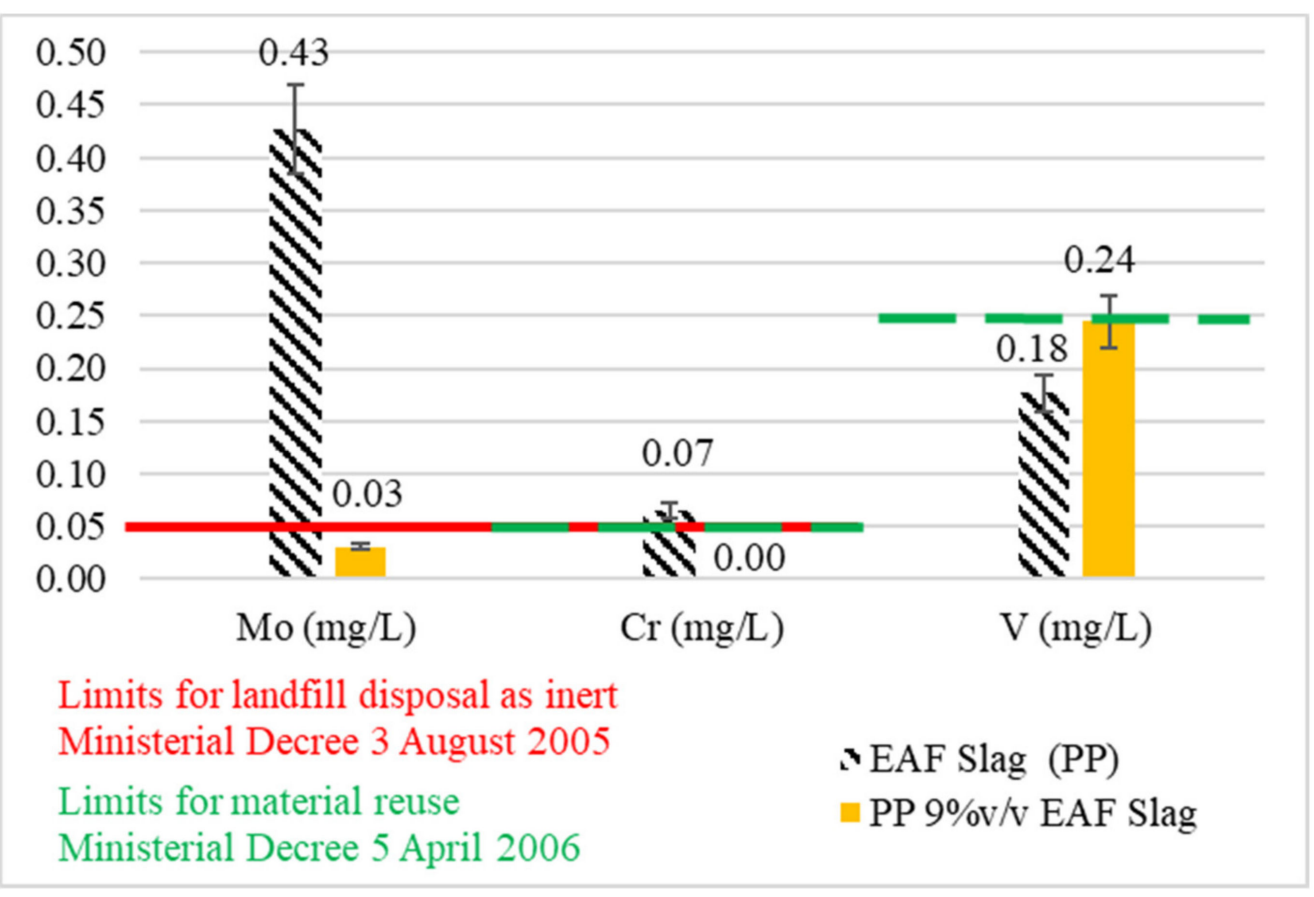

Figure 2. Leaching test results average and standard deviation. The leaching of $\mathrm{Cr}, \mathrm{Mo}$, and $\mathrm{V}$ is determined according to the standard CEN EN 12457-2 on free EAF slag and on NBR, ELT, Epoxy resin and PP filled with EAF slag (grain size < 106). The leaching limits imposed by Italian legislation are shown as horizontal red and green lines.

Tensile Test

Mechanical tensile tests on NBR and ELT filled with EAF slag were performed by a dynamometer (Instron Series 3366) provided by Instron (Pianezza, Turin, Italy) equipped with a $500 \mathrm{~N}$ load cell, at room temperature and at a cross-head rate of $10 \mathrm{~mm} / \mathrm{min}$ according to the standard ISO 37:2017 [48]. The considered strain is the optical one in order to exclude the influence of the sample edges. The measurement is performed at least three times for each material. The purpose of the tensile test is to measure stress and strain at break and tensile elastic modulus.

As regards tensile test of PP filled with EAF slag refer to [31].

\section{Flexural Test}

Flexural test has been performed according to the standard ISO 178:2019 [46] on epoxy resin and resin filled with EAF slag. The purpose of a flexure test is to measure flexural strength and flexural modulus. Tests have been carried out at room temperature $\left(23^{\circ} \mathrm{C}\right)$ by an Instron Series 3366 (Instron, Turin, Italy) universal test machine, equipped with a $10 \mathrm{kN}$ load cell with a crosshead rate of $10 \mathrm{~mm} / \mathrm{min}$ and support span $64 \mathrm{~mm}$. Five $80 \times 4 \times 10 \mathrm{~mm}^{3}$ specimens for each composite are measured. The flexural strength (MPa) is calculated by the following equation:

$$
\sigma_{f \max }=\frac{3 P L}{2 b d^{2}}
$$

where $P$ is the load (N), $L$ is the support span (mm), $b$ is the width (mm), and $d$ is the thickness (mm).

Additionally, flexural elastic modulus is calculated by the following equation:

$$
E_{f}=\frac{P L^{3}}{4 b d^{3} \delta}
$$

where $\delta$ is the deflection $(\mathrm{mm})$. 


\section{Compression Test}

Compression test on epoxy composite has been carried out according to the standard ISO 14544:2016 [47]. The test sample is cylindrical (diameter $10 \mathrm{~mm}$ and height $20 \mathrm{~mm}$ ) and is positioned between two plates which distribute the applied load over the entire surface area of two opposite faces of the test sample. The plates are pushed together with a crosshead rate of $1 \mathrm{~mm} / \mathrm{min}$ by an electromechanical dynamometer (Instron Series 3366, Instron, Turin, Italy) equipped with a $10 \mathrm{kN}$ load cell. The compression test evaluates the response of the material subjected to a compressive load measuring the yield stress, strain at break, and compressive elastic modulus.

As regards NBR and ELT composites, the compression tests were performed with the same test parameters on cylindrical test samples of nominal diameter $12 \mathrm{~mm}$ and high $6 \mathrm{~mm}$.

Hardness Test

Hardness test has been carried out on micro Vickers or microIRHD (Gibitre Instruments Srl, Bergamo, Italy) scale depending on polymer type. The hardness of hard polymers such PP and epoxy resin is measured in micro Vickers, while that of NBR and ELT is measured in microIRHD.

By means of a digital microhardness tester (Hardness testing machine HM-200 provided by Mitutoyo (Kawasaky, Japan)), a $0.3 \mathrm{~N}$ load was applied through the Vickers indenter for $10 \mathrm{~s}$. Vickers Hardness value is calculated according to the following equation:

$$
\mathrm{HV}=1.854 \frac{P}{d}
$$

where $P$ is the load $(\mathrm{N})$ and $d$ is the arithmetic mean of the two diagonals, $d_{1}$ and $d_{2}(\mathrm{~mm})$ of the pyramidal indenter.

Five indentations were performed at different points on each specimen and the mean Vickers Hardness (HV) was calculated.

In the MIRHD measurement, a sample with a thickness of $2 \mathrm{~mm}$ is subjected to a contact force for $3 \mathrm{~s}$ in order to reset the depth measurement system. Then, an additional constant force for 30s is applied so that the depth of penetration is measured according to the standard ISO 48 [52] by the following equation [53]:

$$
\operatorname{IRHD} f(E)=\frac{100}{\sigma \sqrt{2 \pi}} \int_{-\infty}^{\log _{10} E} e^{\frac{(t-a)^{2}}{2 \sigma^{2}}} d t
$$

where:

$E$ is the elastic modulus calculated by on the empirical equation of contact mechanics for a fully elastic isotropic material [38]:

$$
\frac{F}{E}=0.0038 r^{0.65} D^{1.35}
$$

$F$ is the indenting force $(\mathrm{N}), r$ is the radius of the ball $(\mathrm{mm})$, and $D$ is the indentation depth (mm);

$a$ and $\sigma$ are numeric constants;

$t$ is the indentation time (s).

An automatic hardness tester Micro IRHD-PC provided by Gibitre Instruments (Bergamo, Italy), has been used to perform the mIRHD measurements. Five indentations were made at different points on each specimen.

\section{SEM Analysis}

The distribution of slag particles and the micrographs of cross sections of specimens broken in liquid nitrogen and sputtered with gold have been assessed by SEM observations. SEM images have been taken by a LEO EVO 40 SEM (Carl Zeiss, Oberkochen, 
Germany) with accelerating voltage of $20 \mathrm{kV}$ using both secondary (SE) and backscattered (BSD) detectors.

\section{Results}

\subsection{EAF Slag Chemical Composition}

Table 1 shows the chemical composition of the EAF slag determined by XRF. The basicity index IB2 $=\mathrm{CaO} / \mathrm{SiO}_{2}$ is 3.15. It is important to note that if the basicity factor IB4 calculated as $(\mathrm{CaO}+\mathrm{MgO}) /\left(\mathrm{SiO}_{2}+\mathrm{Al}_{2} \mathrm{O}_{3}\right)$ is greater than 1 (as in this case), the glass can form. The glass phase shelves the heavy metals and prevent them from leaching [43]. It is important to highlight that the basicity index is defined as the ratio between the percentage of basic and acidic components and it allows to evaluate important metal-slag balances, such as: oxidizing power of the slag, desulfurization and dephosphoration balance. The simplest expression of the basicity index is expressed as IB2, while IB4 considers more acidic and basic slag components to better assess the bath behavior during the EAF process.

Table 1. EAF slag chemical composition (\%) determined by X-ray fluorescence spectroscopy (XRF) basicity index $\mathrm{IB} 2=\mathrm{CaO} / \mathrm{SiO}_{2}$ and basicity factor IB4 $=(\mathrm{CaO}+\mathrm{MgO}) /\left(\mathrm{SiO}_{2}+\mathrm{Al}_{2} \mathrm{O}_{3}\right)$.

\begin{tabular}{|c|c|c|c|c|c|c|c|c|c|c|c|c|}
\hline $\mathrm{SiO}_{2}$ & $\mathrm{Al}_{2} \mathrm{O}_{3}$ & $\mathrm{Fe}_{2} \mathrm{O}_{3}$ & $\mathrm{MnO}$ & $\mathrm{CaO}$ & $\mathrm{MgO}$ & $\mathrm{P}_{2} \mathrm{O}_{5}$ & $\mathrm{TiO}_{2}$ & $\mathrm{Cr}_{2} \mathrm{O}_{3}$ & $S$ & $\mathrm{Na}_{2} \mathrm{O}$ & $\mathrm{K}_{2} \mathrm{O}$ & $\mathbf{F}$ \\
\hline 9.452 & 7.609 & 40.19 & 5.575 & 29.83 & 3.640 & 0.48 & 0.381 & 2.301 & 0.091 & 0.440 & 0.013 & 0.000 \\
\hline \multicolumn{3}{|c|}{ Sum } & \multicolumn{2}{|c|}{ Basicity } & \multicolumn{2}{|c|}{$\mathrm{CaO} / \mathrm{Al}_{2} \mathrm{O}_{3}$} & \multicolumn{2}{|c|}{$\mathrm{Al}_{2} \mathrm{O}_{3} / \mathrm{SiO}_{2}$} & \multicolumn{2}{|c|}{ IB2 } & \multicolumn{2}{|c|}{ IB4 } \\
\hline \multicolumn{3}{|c|}{101.3024} & \multicolumn{2}{|c|}{0.6177} & \multicolumn{2}{|c|}{3.9224} & \multicolumn{2}{|c|}{0.8050} & \multicolumn{2}{|c|}{3.1574} & \multicolumn{2}{|c|}{1.9627} \\
\hline
\end{tabular}

\subsection{Mechanical Tests}

A rigid filler in polymer matrixes affects composites mechanical characteristics because it reduces the mobility of the matrixes resulting in a stiffening of the filled material. This results in an increase in the elastic modulus $(E)$. Figure 3 shows a comparison between the elastic modulus of neat polymers and the correspondent composite filled with EAF slag. NBR, ELT, and PP were tested by tensile test and epoxy resins were tested by flexural test; the tensile and flexural elastic moduli ( $E t$ and $E f$ ) are reported. Obviously, the elastomeric materials (NBR and ELT) show a lower stiffness than PP and epoxy resin. For this reason, in order to emphasize only the influence of the slag with respect to the unfilled matrix, the elastic modulus is reported in different units of measurement (MPa and GPa). Experimental results show that the presence of EAF slag as filler increases the materials' elastic modulus. The presence of $20 \% v / v$ of EAF slag increases the tensile modulus of NBR and ELT by about $30 \%$ and $20 \%$, respectively. The presence of $30 \% \mathrm{wt}(9 \% v / v)$ increases neat PP tensile modulus by about $20 \%$. The presence of $60 \% \mathrm{wt}(30.3 \% \mathrm{v} / \mathrm{v})$ and $80 \% \mathrm{wt}(53.7 \%$ $v / v$ ) increases the flexural modulus by about $40 \%$ and $60 \%$, respectively.

On the other side, the presence of EAF slag as a filler in polymer matrixes affects the filled materials' maximum stress, as shown in Figure 4. First, it is appropriate to make some considerations on the tensile stress-strain curves of the different polymers: the maximum stress is placed in different curve sections function of matrix material. In elastomers the maximum stress coincides with the tensile stress at break, in PP it coincides with the yielding point before the necking and cold drawing occurs up to the break [54]. As regards the flexural stress-strain curve of the epoxy matrix, the maximum stress coincides with the yielding stress. In Figure 4, it is possible to notice that in thermoset matrixes (NBR, ELT, and epoxy resin) EAF slag reduces the maximum stress, while in the thermo-plastic matrix (PP) it increases the yielding stress by about $20 \%$. This behavior could be explained with a better filler-matrix adhesion: in the PP matrix, the good filler matrix adhesion results in a load distribution between slag particles and polymer matrix. 


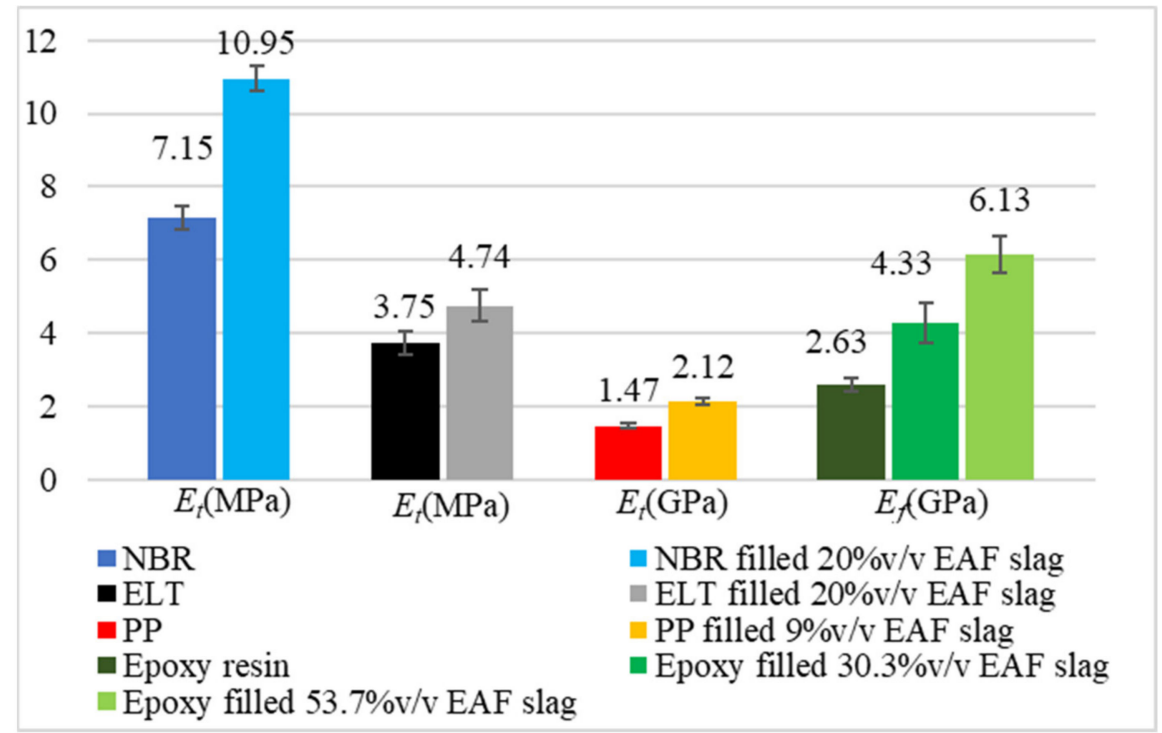

Figure 3. Influence of EAF slag as filler for NBR, ELT, PP, and epoxy resin matrix on elastic modulus.

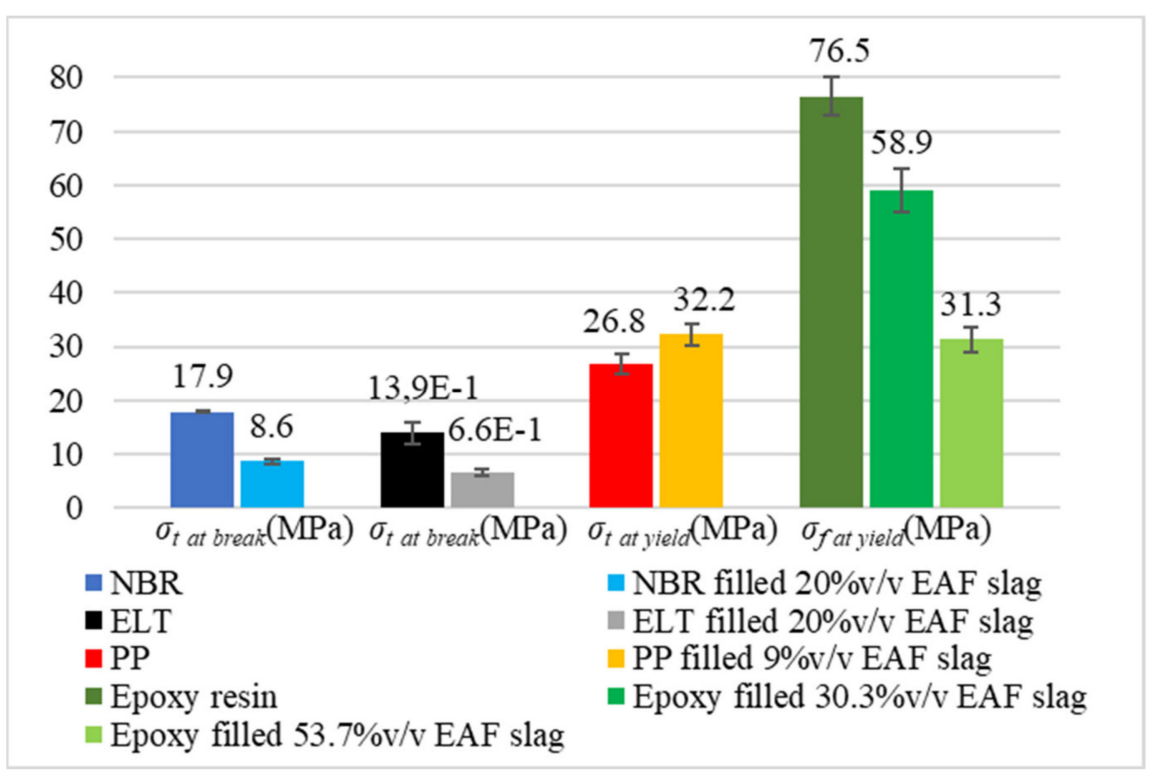

Figure 4. Influence of EAF slag as filler for NBR, ELT, PP, and epoxy resin matrix on maximum stress that coincides with stress at break or stress at yield depending on the polymer matrix.

Extensive literature demonstrated that composite strength is strongly dependent on the interfacial adhesion between filler and matrix [55-59]. The influence of EAF slag as filler for PP was found to be similar to that of other fillers, such as talc [56,60], and calcium carbonate [61]. In the other matrixes, the minor adhesion makes the slag particles possible failure points (especially in ELT composite as shown in SEM observations discussed in Section 3.4. The presence of fillers in elastomer material has been studied in literature [62] and it was found that also in other fillers reinforced NBR the stress at break is reduced $[63,64]$. The rigid particles amplifies the strain of the polymer chains and causing also an amplification in the local stresses due to the hydrodynamic effect. Regarding epoxy composites, according to literature [65], the reduction in flexural strength can be attributed to insufficient particles embedding. For small filler volume fraction the flexural strength increases because the amount of resin between rigid particles allows the filler to bear most of the load. Beyond a certain filler volume fraction flexural strength is reduced due to the poor embedding of the filler particles. In the case of the composites studied in this work, 
it is possible to state that this threshold is lower than $30.3 \% v / v$ of filler (grain size lower than $106 \mu \mathrm{m})$.

It should be noted that in the graph of Figure 4, the ELT data are not proportionate to the others, but they are 10 times enlarged for a better reading of the comparison between ELT and ELT filled with slag.

Experimental results showed that EAF slag as a filler in polymer matrixes also affects the strain of the filled material. In Figure 5, the strain at break is reported for neat and filled polymers. It should be emphasized that the epoxy composites data are not proportionate to the others, but they are 10 times enlarged for a better reading of the comparison between neat epoxy and epoxy filled with slag.

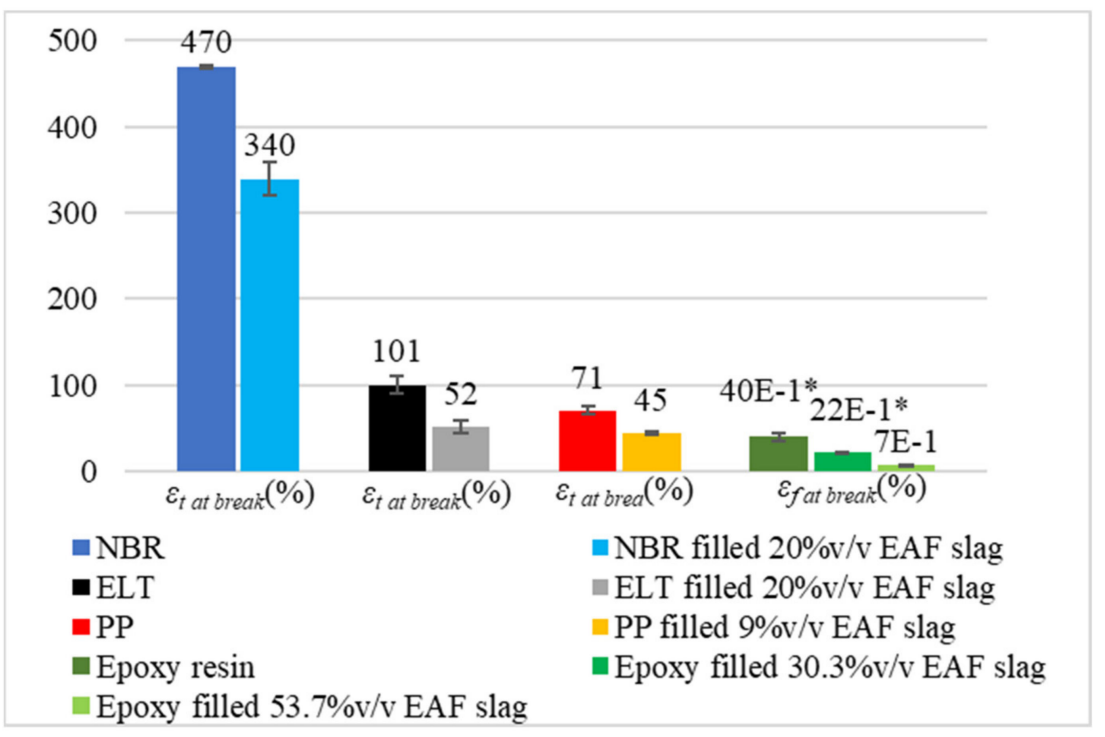

Figure 5. Influence of EAF slag as filler for NBR, ELT, PP, and epoxy resin matrix on strain at break. $\left.{ }^{*}\right)$ Neat epoxy and epoxy filled at $30.3 \% v / v$ yield gradually above the peak; the considered strain at break is the strain at yielding stress.

It is evident that the presence of EAF slag significantly reduces the strain at break of all tested polymer composites. The presence of rigid filler in a polymer matrix on one side stiffens the polymer composite but on the other side, reduces of the mobility of the polymer resulting in a strain reduction. As expected, materials with a higher modulus showed lower strain at break.

It is important to highlight that in real applications the materials should never be stressed up to the ultimate properties, so for some applications, the advantages given by the increase in the elastic modulus are to be considered greater than the penalty of the ultimate strength.

Considering real applications for which rubber and epoxy are used, the compression properties are of major relevance. Due to the production process of the ELT samples by calendering (which allows to produce rubber sheets of a thickness of about $2 \mathrm{~mm}$ ) it was not possible to perform the compression test on this material due to the lack of samples with appropriate geometry (thickness $6 \mathrm{~mm}$ ). In Figure 6, the influence of EAF slag as filler on the compression elastic modulus $(E c)$ of NBR and epoxy composites is reported.

It is possible to observe that the presence of EAF slag at $20 \% v / v$ increases by about $30 \%$ the modulus of composite NBR compared to that of standard NBR. The increase in the compression modulus in sealing systems has a positive effect on the performance of the material. In sealing systems assembled in load control, it results in less deformation on the material with consequent reduction in stress relaxation over the time. On the other side, in sealing systems assembled in displacement control it leads to a greater contact pressure which results in higher fluid pressures. 


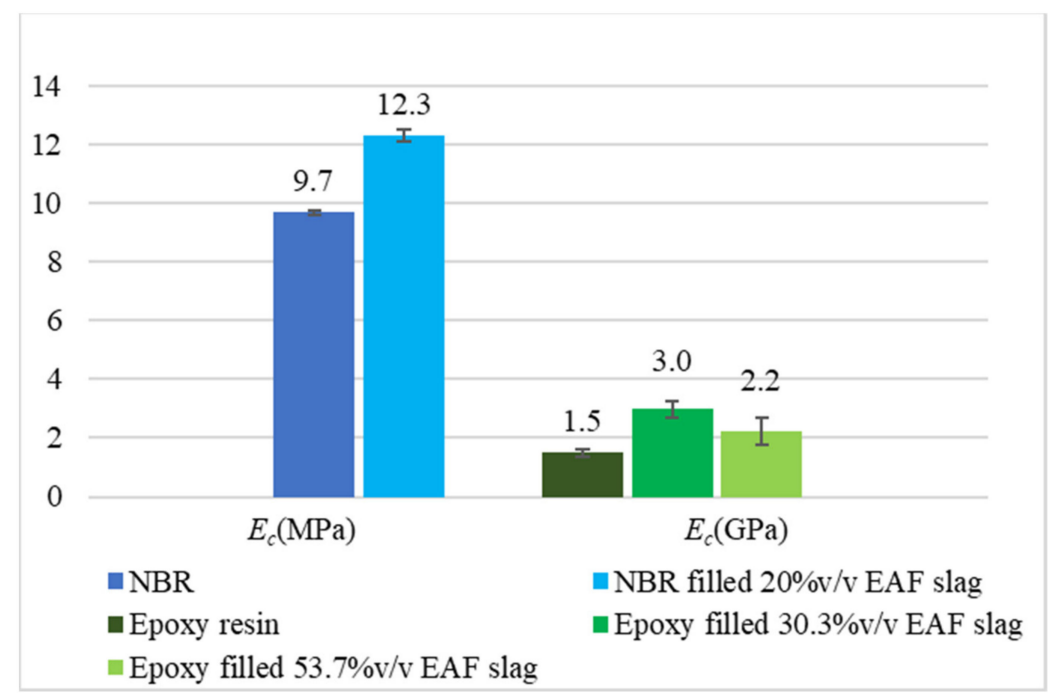

Figure 6. Influence of EAF slag as filler for NBR, ELT, PP, and epoxy resin matrix on compression elastic modulus $\left(E_{c}\right)$.

As regards the influence of slag on epoxy composites' modulus, it is possible to observe that with a slag content of $30.3 \% v / v$ Ec doubled, in fact they reach $1.5 \mathrm{GPa}$ for neat epoxy and 3.0 GPa for composite epoxy. For a slag content of $53.7 \% v / v$, the trend does not continue to grow but undergoes to a slight reduction at $2.2 \mathrm{GPa}$.

The influence of EAF slag as filler in different polymer matrixes has been evaluated also by hardness test and the results are reported in Figure 7. It is possible to note that the slag increases the hardness of all polymer composites considered in this work. This behavior is due to the presence of a rigid filler that reduces the polymer matrixes deformability, resulting in an increase in hardness, as well as elastic modulus.

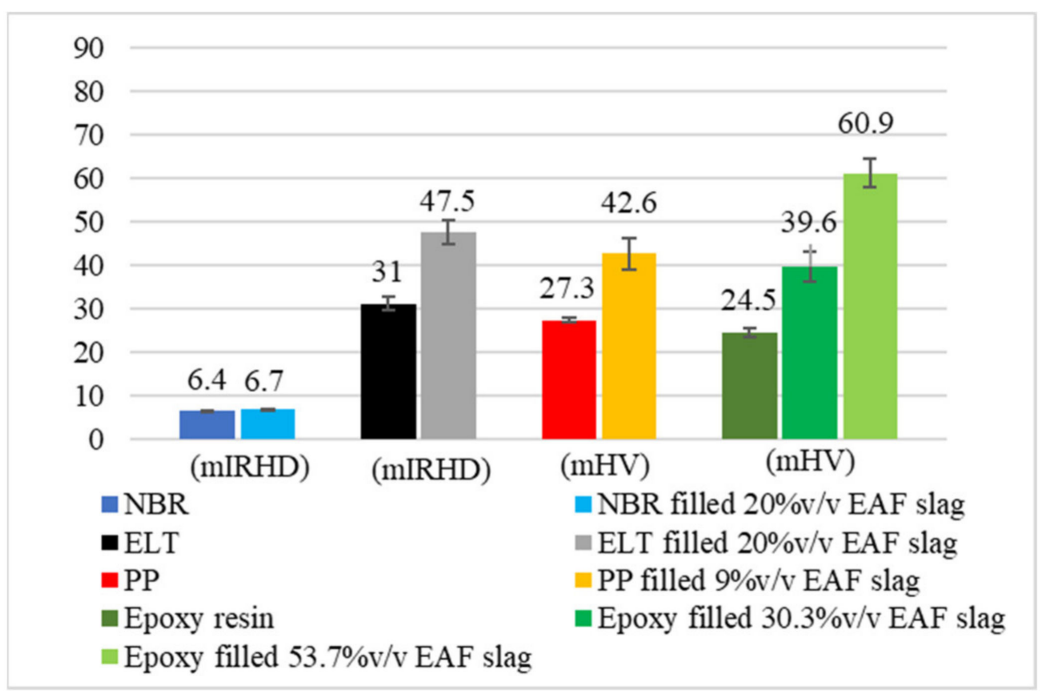

Figure 7. Influence of EAF slag as filler for NBR, ELT, PP, and epoxy resin matrix on hardness mIRHD or $\mathrm{mHV}$ in function of polymer type.

Usually, the hardness of the vulcanized rubber is modulated by the type and quantity of carbon black added to the elastomeric matrix. The increase in hardness due to slag could lead to even partial replacement of carbon black resulting in multiple advantages: economic thanks to the low cost of slag as waste; and environmental as it avoids the pollution caused by the carbon black production (incomplete combustion of heavy petroleum products) and the slag landfilling. 
Similarly, the slag also increases the hardness of the ELT recycled composite. This result leads to an increase in one of the most important rubber characteristics in a $100 \%$ recycled composite.

As regards PP and epoxy, the slag could replace of traditional fillers such as talc or calcium carbonate and sand, respectively.

\subsection{Leaching Test}

Table 2 shows the concentration of $\mathrm{Mo}, \mathrm{Cr}, \mathrm{V}, \mathrm{Cu}, \mathrm{As}$, and $\mathrm{Cd}$ in the leachates of the EAF slag used as filler for NBR, ELT and epoxy matrixes. Is it possible to notice that the concentration of $\mathrm{Cu}, \mathrm{As}$, and $\mathrm{Cd}$ in leachates is far below the permitted threshold so that their concentration in the composites leachates is assumed to be neglectable.

Figure 2 shows the $\mathrm{Mo}, \mathrm{Cr}$, and $\mathrm{V}$ leaching of free EAF slag and of different composites. The composites consists of a polymer matrix (NBR, ELT, epoxy resin and PP) filled with different amount of EAF slag. As horizontal lines, the leaching limit according to the Italian legislation are highlighted.

Table 2. Leaching test results of EAF slag with grain size less than $4 \mathrm{~mm}$.

\begin{tabular}{cccc}
\hline Element & Concentration [mg/L] & $\begin{array}{c}\text { Limits for Landfill Disposal as Inert } \\
\text { Ministerial Decree 3 August 2005 [mg/L] }\end{array}$ & $\begin{array}{c}\text { Limits for Material Reuse Ministerial } \\
\text { Decree 5 April 2006 [mg/L] }\end{array}$ \\
\hline $\mathrm{Mo}$ & 0.15 & 0.05 & - \\
\hline $\mathrm{Cr}$ & 0.07 & 0.05 & 0.05 \\
\hline $\mathrm{V}$ & 0.15 & - & 0.25 \\
\hline $\mathrm{Cu}$ & 0.01 & 0.05 & 0.05 \\
\hline $\mathrm{As}$ & 0.005 & 0.05 & 0.05 \\
\hline $\mathrm{Cd}$ & 0.0005 & 0.005 & 0.005 \\
\hline
\end{tabular}

Italian Ministerial Decree 5 April 2006 [29] defines criteria and features for nonhazardous waste reuse. It imposes the concentration limits for several parameters, including $\mathrm{Cr}$ and $\mathrm{V}$. Dotted green lines highlight $\mathrm{Cr}$ and $\mathrm{V}$ concentration limits in Figure 2. Experimental results demonstrated that the tested free EAF slags (both that used as filler for NBR, ELT and epoxy matrix, and that used as filler for PP matrix [31]) are non-compliant for reuse because their $\mathrm{Cr}$ leaching exceeds the limit of $0.05 \mathrm{mg} / \mathrm{L}$ imposed by Ministerial Decree 5 April 2006. On the other side, if the slag is incorporated in polymer matrixes the leaching of $\mathrm{Cr}$ is reduced within the limit of $0.05 \mathrm{mg} / \mathrm{L}$ making the composite material compliant for reuse according to the Ministerial Decree 5 April 2006 [29]. As for V, their leaching into free slag is already well below the limit allowed for reuse. As for PP and NBR matrixes the leaching of $V$ is not markedly changed, and the small variations are attributable to the intrinsic heterogeneity of the slag.

When waste material is not compliant to be recovered, the landfill is an inevitable destination. However, also landfilling is regulated, and Italian Ministerial decree 3 August 2005 [30] categorizes the types of waste on the basis of certain characteristics (including leaching of certain elements) for greater protection of the environment. As the waste category increases (inert, non-hazardous, hazardous), the related disposal costs also increase. Among the elements considered are $\mathrm{Cr}$ and Mo whose leaching limit for landfilling as inert $(0.05 \mathrm{mg} / \mathrm{L})$ is highlighted in Figure 2 by a solid red line. The same considerations as above can be completed for $\mathrm{Cr}$ concentration. As regards Mo leaching, experimental results show a great reduction for the NBR and PP matrixes that makes these composites compliant to be disposed of as inert waste. A slight reduction in Mo leaching was found in an epoxy resin filled with EAF slag at $30.3 \% v / v$ but it is not enough to comply with the leaching limit of $0.05 \mathrm{mg} / \mathrm{L}$. The greater release of Mo in these composites is not attributable to the polymer matrices. Epoxy resin does not contain this element and the leaching test conducted on the ELT powder showed a release of $\mathrm{Mo}, \mathrm{Cr}$, and $\mathrm{V}$ equal to zero. 
It is important to highlight that the slag tested as free slag and that tested in polymer matrixes does not consist in exactly the same EAF slag particles, but it belongs to the same casting. Small leaching variation can be attributable to the intrinsic heterogeneity of the slag.

In ELT composite the rubber is recycled and, compared to NBR composite (where the vulcanization takes place around slag particles), shows less. In epoxy composite filled at $62.1 \% v / v$, the capacity of the epoxy matrix to in-corporate the slag is obviously lower than that of epoxy filled at 35.3\% $v / v$ due to a greater filler content cohesion (see SEM observations discussed in Section 3.4).

Nevertheless, it is also important to highlight the influence of the EAF slag particle size on hazardous elements leaching. In these experimental results, the Mo leaching of fi-ne slag increases although slag particles are incorporated in epoxy and ELT matrixes. It is also important to highlight that the leaching test on EAF slag used as filler for PP matrix has been carried out on a fine slag, so that its leaching behavior was affected by particles size. Nevertheless, only Mo shows a marked increase in leachate concentration. According to the experimental results, it seems that Mo is the most sensitive element slag particles size on leaching behavior.

Extensive literature research [20,49-51] demonstrated that with reducing the slag particle size the heavy metals leaching increases. For this reason, since the EAF slag particle size is drastically reduced in composites (less than $4 \mathrm{~mm}$ for free slag and less than $106 \mu \mathrm{m}$ in composites), it is not wrong to state that the incorporation of slag in a polymer matrix has an intertizing effect on leaching behavior.

\subsection{SEM Observations}

Figure 8 shows SEM backscattering images of cross sections of the different composites broken in liquid nitrogen. The distribution and the dispersion of EAF slag particles of a size lower than 106 microns in the different polymer matrixes appears to be homogeneous.

NBR composite (Figure 8a) shows a uniform matrix within which the particles are well distributed and incorporated, especially the slag particles of a size lower than $50 \mu \mathrm{m}$. At the edges of the larger particles there seems to be a small gap given by a lower adhesion between the filling and the matrix.

In ELT composite (Figure 8b) it is possible to notice that the polymer matrix is not well cohesive and uniform, but it presents some discontinuities probably in correspondence of rubber powder edges that in the calendering process did not blend with each other. As regarding the incorporation of slag particles, the same considerations as for NBR composite can be completed.

In PP composite (Figure 8c) the lower amount of EAF slag is observable, moreover the incorporation of particles slag in the matrix is excellent. This confirms both the results obtained by mechanical tests (where PP is the only composite showing an increase in the yielding stress) and the leaching test results where the release of $\mathrm{Cr}, \mathrm{V}$, and Mo is markedly reduced.

As regarding epoxy resin composites (Figure 8), the greater amount of EAF slag is clearly visible, therefore the amount of resin that incorporates the slag particles is lower than in other composites, especially in the epoxy filled at $62.1 \% v / v$. This is congruent with what was found in the leaching test results, where for a lower quantity of resin the release of Mo, Cr, and V is greater. It is interesting to highlight that the epoxy-slag adhesion seems excellent but nevertheless the flexural yielding stress is reduced by the presence of EAF slag. Nevertheless, some areas with poor filler-matrix interaction and pulled-out particles are observable in Figure 9d.

Figure 9a shows the micrographs of cross sections of the different composites broken in liquid nitrogen in order to evaluate the quality of the particle slag incorporation into the polymer matrixes. It is possible to notice that in Figure 9a the small particles are well incorporated into the NBR matrix, while the largest particles are more prone to be pulled out form the matrix. In Figure $9 b$ the less adhesion of the matrix is visible by numerous 
voids, especially around the largest slag particles. Figure 9c shows a particle slag well incorporated into the PP matrix with-out micro voids at the edges of the slag particle. In Figure $9 \mathrm{~d}$, it is possible to observe a de-bounding between the filler particle and the epoxy matrix which was not observable in backscattering SEM images. In a high filled epoxy resin $(62.1 \% v / v)$ micrograph, it is possible to observe the voids left by the pulled out particles. All these considerations are in line with the leaching and mechanical test results.

(a) NBR $20 \%[v / v]$ EAF Slag

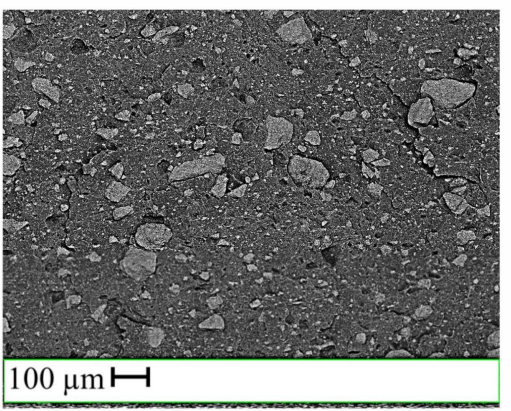

(c) PP $9 \%[v / v]$ EAF Slag

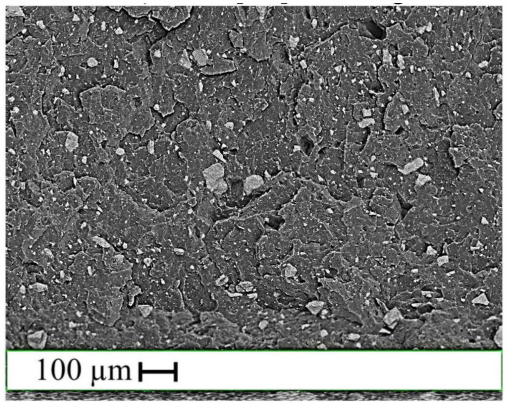

(b) ELT $20 \%[v / v]$ EAF Slag

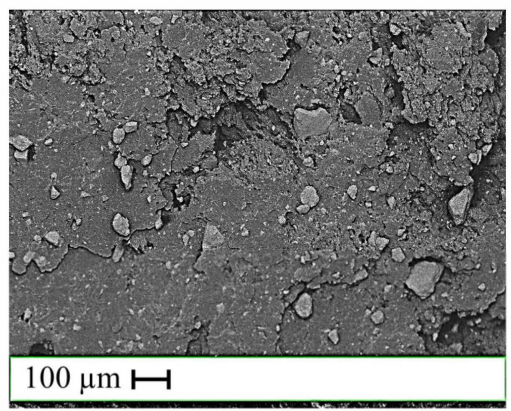

(d) Epoxy resin 35.5\%[v/v] EAF Slag Epoxy resin $62.1 \%[v / v]$ EAF Slag

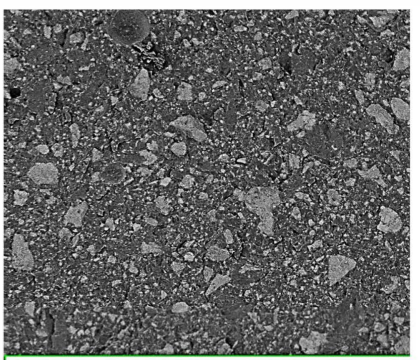

$100 \mu \mathrm{m} \longmapsto$

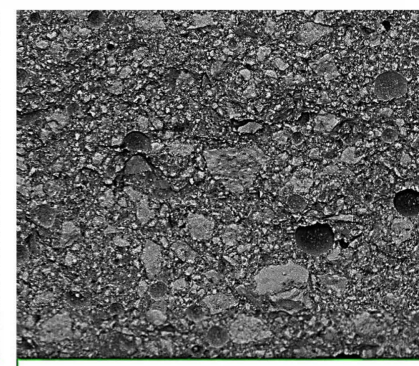

$100 \mu \mathrm{m} \longmapsto$

Figure 8. SEM backscattering images of cross sections of specimens broken in liquid nitrogen. (a) NBR filled with EAF slag 20\% $(v / v)$. (b) ELT filled with EAF slag 20\% $(v / v)$. (c) PP filled with EAF slag 9\% $(v / v)$. (d) Epoxy resin filled with EAF slag $35.5 \%(v / v)$. and $62.1 \%(v / v)$.

(a) NBR $20 \%[v / v]$ EAF Slag

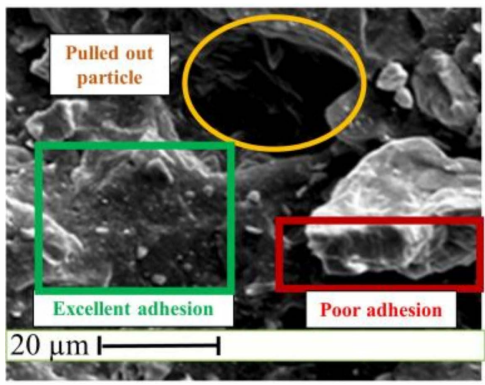

(c) PP 9\%[v/v] EAF Slag

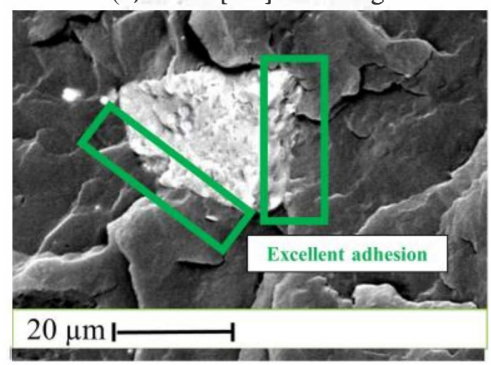

(b) ELT $20 \%[v / v]$ EAF Slag

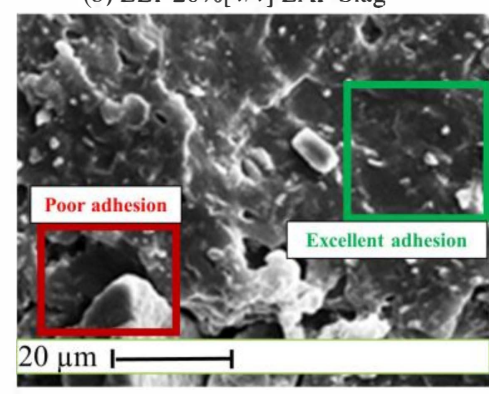

(d) Epoxy resin $35.5 \%[v / v]$ EAF Slag Epoxy resin $62.1 \%[v / v]$ EAF Slag
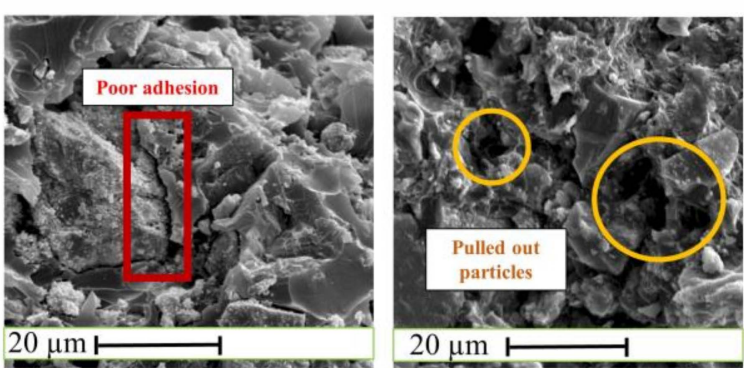

Figure 9. SEM micrograph of cross sections of specimens broken in liquid nitrogen. (a) NBR filled with EAF slag $20 \%$ $(v / v)$. (b) ELT filled with EAF slag 20\% $(v / v)$. (c) PP filled with EAF slag 9\% $(v / v)$. (d) Epoxy resin filled with EAF slag $35.5 \%(v / v)$. and $62.1 \%(v / v)$. 


\section{Discussion}

In the present study, the chemical composition of the slag was determined by X-ray fluorescence and the leaching rate of $\mathrm{Cr}$, Mo, and $\mathrm{V}$ was determined according to the standard CEN EN 12457-2 [25] both on the free slag and on the composite materials (polymer/EAF slag). It has been found that, although EAF slags can release small amounts of hazardous elements, incorporating it into polymer matrix to a leaching reduction.

The polymeric matrixes used in this research work are very different from each other as they belong to 3 different categories of plastic materials: thermoplastic, thermosetting, and elastomeric. The fourth matrix consists of end-of-life tires, a waste material whose use is of great environmental interest.

Thermoplastics, including PP, are materials that usually are processed in the molten state and return to the solid-state when cooled; this process can be repeated just by heating the polymer.

Thermosets, including epoxy resin, react to heat first by softening and then return to harden due to a three-dimensional crosslinking process.

Thanks to the combined effect of heat and pressure, a shape can be given to thermosetting materials. Unlike thermoplastics, the process cannot be repeated because when heated again, thermosets tend to decompose and carbonize.

Elastomers are materials characterized by high deformability and elasticity. The elastomers used in this study are of two types: thermosetting nitrile butadiene rubber (NBR) widely used in the field of gaskets, and recycled rubber tires (ELT).

Cornacchia et al. [31] were the first to propose an innovative use of EAF slag as a filler for PP matrix as a replacement of traditional fillers such as calcium carbonate. Following in the footsteps of that work, in this study the use of EAF slag to replace the traditional silica for laying epoxy screeds is proposed. The epoxy screed is a particular type of resin flooring characterized by a very high thickness, generally between 6 and $15 \mathrm{~mm}$, which guarantees excellent mechanical resistance, resistance to foot traffic, and chemical agents. The innovative applications of EAF slag as traditional fillers replacement have the great environmental advantage of offering second life to the slag that otherwise would have been disposed of in landfills and not requires further exploitation of non-renewable natural resources.

Regarding the influence of slag as a filler for a NBR matrix, it has been found that it positively affects the behavior of a gasket assembled in a sealing system and also significantly reduces the costs of the raw material, as a volumetric fraction of virgin rubber is re-placed with a waste material.

Finally, since the problem of ELT disposal is a crucial environmental issue, as well as that of EAF slag disposal, a 100\% waste material has been compounded and characterized. This new material is suitable for applications that do not require high mechanical performance, and can lead to both environmental benefits and economic benefits.

The influence of EAF slag as a filler for different polymer matrixes was evaluated in terms of matrix inertizing effect on the leaching of hazardous elements and mechanical properties. The incorporation of EAF slag particles in a polymer matrix reduces heavy metals leaching. In particular, the influence on $\mathrm{Mo}, \mathrm{Cr}$, and $\mathrm{V}$ leaching makes the polymer composites compliant for reuse, according to the Italian Ministerial Decree 5 April 2006 [29]. As regards the landfill disposal as inert waste according to the Italian Ministerial Decree 3 August 2005 [30] the leaching of Mo exceeds the imposed threshold limit of $0.05 \mathrm{mg} / \mathrm{L}$ even in composite materials. This behavior could be attributed the influence of EAF grain size on the leaching behavior and to the intrinsic heterogeneity of the slag.

Among the hazardous elements leaching, when the slag comes in contact with water the calcium and magnesium oxides hydrate resulting in expansion phenomena [23]. The incorporation of slag particles in polymers matrixes reduces the hydration due to the water resistance of the proposed materials. Where the incorporation is not optimal, that is the case of ELT, the elastomeric matrix thank to its high deformability, can compensate small volume variations. 
The distribution of slag particles in the composites and the morphology of the cross section of specimens fractured in nitrogen were assessed by SEM observations. The polymers considered are very different from each other, so it is possible to observe only partially common behaviors. Nevertheless, this study allows to highlight the characteristics and benefits of the individual filled polymers with respect to their typology.

NBR is a vulcanized rubber widely used in the gasket industry. It consists of an elastomeric network in which the macromolecules are linked together both by physical bonds (entanglements) and by covalent chemical bonds. The basic elastomer is filled with various additives, first, the carbon black that increases the mechanical properties. The presence of slag as filler in this polymer matrix, which is vulcanized after incorporation of the slag, leads to the production of a composite more rigid than standard NBR but also less deformable and less resistant. This mechanical behavior shows how on one hand the rig-id particles of the slag reduce the mobility of the polymer matrix by stiffening it, and on the other hand, the reduction in tensile ultimate properties may be due minor adhesion between slag and NBR confirmed by SEM images. This phenomenon does not allow to share the applied load on matrix and filler. As already pointed out, rarely a rubber part works in the tensile condition in real applications, but rather it works in sealing systems. It was found that EAF slag as filler for NBR matrix positively affects the composite characteristics assembled in sealing systems. Furthermore, the use of EAF slag as filler leads to several environmental and economic benefits, not least the reduction in $\mathrm{Cr}$ and $\mathrm{Mo}$ leaching below the threshold limits imposed by the legislation for slag reuse or disposal as inert waste.

As regards ELT composite, the influence of slag on the mechanical properties of the ELT is analogous to that on NBR, however, the material is significantly different, and some considerations need to be made on the reasons behind the mechanical results. First of all it is opportune to make an aside about the ELT issue. Approximately 3 billion tires/year worldwide reach their end of life [32]. Although about $70 \%$ of this quantity is recovered, the largest percentage is intended for energy production which is the last option before the landfilling, according to the waste hierarchy of the European Directive $2000 / 53 / E C[33,66]$. This work proposes a method of ELT material reuse (preferable to energy recovery) by calendering. As the experimental results show, this recycled material has lower mechanical properties than a virgin vulcanized rubber, as expected, but for some applications it can meet the requirements, resulting in a very advantageous solution from both an environmental and an economic point of view. Furthermore, the addition of another waste material, such as slag, can increase some properties (such as elastic modulus and hardness). As regards heavy metals leaching of particles slag incorporated into ELT matrix, a reduction was found for $\mathrm{Cr}$ and $\mathrm{V}$ leaching making the material compliant for reuse according to Ministerial Decree 5 April 2006 [29].

The influence of EAF slag as filler in thermoplastic PP matrix was found to be promising as traditional filler replacement (such as talc and calcium carbonate) due to the increase not only in hardness and elastic modulus but also in tensile strength [35] evidencing a filler-matrix adhesion better than that of others tested polymer matrixes.

As last, the use of EAF slag as filler in epoxy matrix showed an increase in flexural and compression elastic modulus. The influence of EAF slag on the epoxy resin is similar to that of other traditional fillers such as silica and alumina particles [43]. This means EAF slag could represent an alternative filler for epoxy resins resulting in saving raw material costs and the preservation of natural resources.

\section{Conclusions}

In the present work, an innovative use of EAF slag is presented, i.e., as a filler in different polymeric matrices (NBR, ELT, PP, and epoxy resin). The experimental results demonstrated that:

1. The distribution and the dispersion of EAF slag particles in the different polymer matrixes is homogeneous and good adhesion between filler and matrix is observed; 
2. The incorporation of EAF slag particles in a polymer matrix reduces heavy metals leaching:

1. The influence on $\mathrm{Cr}$, and $\mathrm{V}$ leaching makes the polymer composites compliant for reuse, according to the Italian Ministerial Decree 5 April 2006 [29]; The influence on $\mathrm{Cr}$ and Mo makes NBR and PP composites compliant to be disposed of as inert waste, according to the Italian Ministerial Decree 3 August 2005 [30]; For ELT and Epoxy composites Mo leaching exceeds the limit of $0.05 \mathrm{mg} / \mathrm{L}$,

2. The presence of EAF slag as filler increases the elastic modulus and the hardness of polymer composites although it reduces the ultimate properties (except for PP);

3. The reasons behind the mechanical behavior of the tested composites are to be found in the different nature and production processes of the polymeric matrices.

In conclusion, a more in-depth study of this innovative application of EAF slag can not only reduce the amount of waste disposed of in landfills but also reduce the consumption of virgin raw materials, which, if replaced by a waste material, will result in significant savings for manufacturing industries.

Author Contributions: Conceptualization, G.C., G.R. and A.G.; methodology, G.C., G.R. and A.G.; writing—original draft preparation, A.G.; writing—review and editing, G.C and G.R.; visualization, G.C and G.R.; supervision, G.R.; project administration, G.R.; funding acquisition, G.R. All authors have read and agreed to the published version of the manuscript.

Funding: This research is part of the Ph.D. scholarship of AG funded by Lombardy Region and ENEA.

Data Availability Statement: The data presented in this study are available in: Cornacchia, G.; Agnelli, S.; Gelfi, M.; Ramorino, G.; Roberti, R. Reuse of EAF slag as reinforcing filler for polypropylene matrix composites. JOM 2015, 67, 1370-1378, doi:10.1007/s11837-015-1396-6. Anna Gobetti, Giovanna Cornacchia, Giorgio Ramorino, Alessandro Riboldi, Laura E. Depero, EAF slag as alternative filler for epoxy screeds, an example of green reuse, SMET 2021, 29, e00324, ISSN 2214-9937, https://doi.org/10.1016/j.susmat.2021.e00324.

Acknowledgments: Authors thank Asonext Spa (Ospitaletto BS, Italy) and Novotema S.p.A-Idex Corporation (Villongo BG, Italy) for providing materials and test equipment for the characterization of EAF slag and NBR composites, and Ges Tyre (Brescia, Italy) for providing ELT powder.

Conflicts of Interest: The authors declare no conflict of interest.

\section{References}

1. European Commission directive 2008/98/EC of the European Parliament and of the Council. Available online: https://eur-lex. europa.eu/LexUriServ/LexUriServ.do?uri=OJ:L:2008:312:0003:0030:en:PDF (accessed on 24 April 2021).

2. European Commission. European Commission Communication from the Commission-Towards a circular economy: A zero waste programme for Europe. Eur. Comm. 2014. [CrossRef]

3. Federacciai. L'Industria Siderurgica Italiana; Federacciai: Milan, Italy, 2019.

4. Teo, P.T.; Zakaria, S.K.; Salleh, S.Z.; Taib, M.A.A.; Sharif, N.M.; Seman, A.A.; Mohamed, J.J.; Yusoff, M.; Yusoff, A.H.; Mohamad, M.; et al. Assessment of electric arc furnace (EAF) steel slag waste's recycling options into value added green products: A review. Metals 2020, 10, 1347. [CrossRef]

5. Eurofer. European Steel in Figures 2020; Eurofer: Brussels, Belgium, 2020.

6. Yi, H.; Xu, G.; Cheng, H.; Wang, J.; Wan, Y.; Chen, H. An overview of utilization of steel slag. Procedia Environ. Sci. 2012. [CrossRef]

7. Pasetto, M.; Baldo, N. Experimental evaluation of high performance base course and road base asphalt concrete with electric arc furnace steel slags. J. Hazard. Mater. 2010. [CrossRef]

8. Yaragal, S.C.; Chethan Kumar, B.; Jitin, C. Durability studies on ferrochrome slag as coarse aggregate in sustainable alkali activated slag/fly ash based concretes. Sustain. Mater. Technol. 2020, 23. [CrossRef]

9. Kolawole, J.T.; Babafemi, A.J.; Paul, S.C.; du Plessis, A. Performance of concrete containing Nigerian electric arc furnace steel slag aggregate towards sustainable production. Sustain. Mater. Technol. 2020, 25. [CrossRef]

10. Zannerni, G.M.; Fattah, K.P.; Al-Tamimi, A.K. Ambient-cured geopolymer concrete with single alkali activator. Sustain. Mater. Technol. 2020, 23. [CrossRef]

11. El-Gamal, S.M.A.; Selim, F.A. Utilization of some industrial wastes for eco-friendly cement production. Sustain. Mater. Technol. 2017, 12, 9-17. [CrossRef] 
12. Shaikh, F.U.A.; Hosan, A. Effect of nano silica on compressive strength and microstructures of high volume blast furnace slag and high volume blast furnace slag-fly ash blended pastes. Sustain. Mater. Technol. 2019, 20. [CrossRef]

13. Carvalho, S.Z.; Vernilli, F.; Almeida, B.; Demarco, M.; Silva, S.N. The recycling effect of BOF slag in the portland cement properties. Resour. Conserv. Recycl. 2017. [CrossRef]

14. Skaf, M.; Manso, J.M.; Aragón, Á.; Fuente-Alonso, J.A.; Ortega-López, V. EAF slag in asphalt mixes: A brief review of its possible re-use. Resour. Conserv. Recycl. 2017, 120, 176-185. [CrossRef]

15. Poh, H.Y.; Ghataora, G.S.; Ghazireh, N. Soil stabilization using basic oxygen steel slag fines. J. Mater. Civ. Eng. 2006. [CrossRef]

16. Gelfi, M.; Cornacchia, G.; Conforti, S.; Roberti, R. Caratterizzazione di scorie di acciaieria e studio del rilascio di cromo. In Proceedings of the Atti di Convegno 33 Convegno Nazionale AIM, Brescia, Italy, 10-12 November 2010; AIM-Associazione Italiana di Metallurgia: Milano, Italy, 2010.

17. Roberti, R.; Uberto, F.; Svanera, M.; Altenburger, G.; Cabra, F. The SLAG-REC ®project for an innovative direct dry granulation of EAF slag. In Proceedings of the 5th Global Slag Conference Pro Global Media Ltd., Brussels, Belgium, 23-24 November 2009; Pro Global Media: Epsom, UK, 2009.

18. Mombelli, D.; Mapelli, C.; Barella, S.; Di Cecca, C.; Le Saout, G.; Garcia-Diaz, E. The effect of microstructure on the leaching behaviour of electric arc furnace (EAF) carbon steel slag. Process Saf. Environ. Prot. 2016. [CrossRef]

19. Mombelli, D.; Gruttadauria, A.; Barella, S.; Mapelli, C. The influence of slag tapping method on the efficiency of stabilization treatment of electric arc furnace carbon steel slag (EAF-C). Minerals 2019, 9, 706. [CrossRef]

20. Riboldi, A.; Cornacchia, G.; Gelfi, M.; Borgese, L.; Zacco, A.; Bontempi, E.; Boniardi, M.V.; Casaroli, A.; Depero, L.E. Grain size effect in elution test of electric arc furnace slag. Appl. Sci. 2020, 10, 477. [CrossRef]

21. Menad, N.E.; Kana, N.; Seron, A.; Kanari, N. New eaf slag characterization methodology for strategic metal recovery. Materials 2021, 14, 1513. [CrossRef] [PubMed]

22. Yildirim, I.Z.; Prezzi, M. Chemical, mineralogical, and morphological properties of steel slag. Adv. Civ. Eng. 2011. [CrossRef]

23. Pellegrino, C.; Gaddo, V. Mechanical and durability characteristics of concrete containing EAF slag as aggregate. Cem. Concr. Compos. 2009. [CrossRef]

24. European Committee for Standardization. CEN EN 12457-1 Characterisation of Waste-Leaching-Compliance Test for Leaching of Granular Waste Materials and Sludges_-Part 1: One Stage Batch Test at a Liquid to Solid Ratio of 2 1/kg for Materials with High Solid Content and With Particle Size below $4 \mathrm{~mm}$; European Committee for Standardization: Brussels, Belgium, 2002.

25. European Committee for Standardization. CEN CEN EN 12457-2 Characterisation of Waste_Leaching - Compliance Test for Leaching of Granular Waste Materials and Sludges_Part 2: One Stage Batch Test at a Liquid to Solid Ratio of $10 \mathrm{l} / \mathrm{kg}$ for Materials with Particle Size below $4 \mathrm{~mm}$; European Committee for Standardization: Brussels, Belgium, 2002.

26. European Committee for Standardization. CEN EN 12457-3 Characterisation of Waste Leaching Compliance Test for Leaching of Granular Waste Materials and Sludges Part 3: Wo Stage Batch Test at a Liquid to Solid Ratio of $2 \mathrm{l} / \mathrm{kg}$ and $8 \mathrm{l} / \mathrm{kg}$ for Materials with a High Solid Content and with a Particle Size; European Committee for Standardization: Brussels, Belgium, 2002.

27. European Committee for Standardization. CEN EN 12457-4 Characterisation of Waste Leaching Compliance Test for Leaching of Granular Waste Materials and Sludges Part 4: One Stage Batch Test at a Liquid to Solid Ratio of $10 \mathrm{l} / \mathrm{kg}$ for Materials with Particle Size below $10 \mathrm{~mm}$ (without or with Size Reduct); European Committee for Standardization: Brussels, Belgium, 2002.

28. Rodgers, K.J.; Hursthouse, A.; Cuthbert, S. The potential of sequential extraction in the characterisation and management of wastes from steel processing: A prospective review. Int. J. Environ. Res. Public Health 2015, 12, 11724-11755. [CrossRef]

29. Ministero della Tutela dell'Ambiente e del Territorio. Gazzetta Ufficiale 19 Maggio 2006, n. 115 Individuazione dei Rifiuti non Pericolosi Sottoposti alle Procedure Semplificate di Recupero, ai Sensi Degli Articoli 31 e 33 del Decreto Legislativo 5 febbraio 1997, n. 22; Ministero della Tutela dell'Ambiente e del Territorio: Rome, Italy, 1997.

30. Ministero della Tutela dell'Ambiente e del Territorio. Gazzetta Ufficiale del 30 Agosto 2005, n. 201 Definizione dei Criteri di Ammissibilità dei Rifiuti in Discarica; Ministero della Tutela dell'Ambiente e del Territorio: Rome, Italy, 2005.

31. Cornacchia, G.; Agnelli, S.; Gelfi, M.; Ramorino, G.; Roberti, R. Reuse of EAF slag as reinforcing filler for polypropylene matrix composites. JOM 2015, 67, 1370-1378. [CrossRef]

32. Grammelis, P.; Margaritis, N.; Dallas, P.; Rakopoulos, D.; Mavrias, G. A review on management of end of life tires (ELTs) and alternative uses of textile fibers. Energies 2021, 14, 571. [CrossRef]

33. Battista, M.; Gobetti, A.; Agnelli, S.; Ramorino, G. Post-consumer tires as a valuable resource: Review of different types of material recovery recovery. Environ. Technol. Rev. 2021. [CrossRef]

34. Martín-Cortés, G.R.; Esper, F.J.; Santana de Araujo, A.J.; Hennies, W.T.; Silva Valenzuela, M.G.; Valenzuela-Díaz, F.R. Replacement of Carbon Black on Natural Rubber Composites and Nanocomposites_Part 1; Springer: Cham, Switzerland, 2016 ; ISBN 9783319481913.

35. Peterson, S.C.; Chandrasekaran, S.R.; Sharma, B.K. Birchwood biochar as partial carbon black replacement in styrene-butadiene rubber composites. J. Elastomers Plast. 2016, 48, 305-316. [CrossRef]

36. Li, C.; Huang, F.; Wang, J.; Liang, X.; Huang, S.; Gu, J. Effects of partial replacement of carbon black with nanocrystalline cellulose on properties of natural rubber nanocomposites. J. Polym. Eng. 2018, 38, 137-146. [CrossRef]

37. Yuvaraj, P.; Rao, J.R.; Fathima, N.N.; Natchimuthu, N.; Mohan, R. Complete replacement of carbon black filler in rubber sole with $\mathrm{CaO}$ embedded activated carbon derived from tannery solid waste. J. Clean. Prod. 2018, 170, 446-450. [CrossRef]

38. Jumahat, A.; Soutis, C.; Mahmud, J.; Ahmad, N. Compressive properties of nanoclay/epoxy nanocomposites. Procedia Eng. 2012, 41, 1607-1613. [CrossRef] 
39. Al-Namie, I.; Ibrahim, A.A.; Hassan, M.F. Study the Mechanical Properties of Epoxy Resin Reinforced With silica (quartz) and Alumina Particles. Iraqi J. Mech. Mater. Eng. 2011, 11, 486-506.

40. Ilyushechkin, A.Y.; Roberts, D.G.; French, D.; Harris, D.J. IGCC Solids Disposal and Utilisation, Final Report for ANLEC Project 50710-0065; Technical Report; Commonwealth Scientific and Industrial Research Organisation (CSIRO): Canberra, Australia, 2012.

41. Petrík, J.; Blaško, P.; Mikloš, V.; Pribulová, A.; Futaš, P.; Vasilňaková, A.; Šolc, M. The load dependence of the micro-hardness of the blast furnace slag. Metall. Mater. Eng. 2020, 26. [CrossRef]

42. Engström, F.; Adolfsson, D.; Yang, Q.; Samuelsson, C.; Björkman, B. Crystallization behaviour of some steelmaking slags. Steel Res. Int. 2010. [CrossRef]

43. Tossavainen, M.; Engstrom, F.; Yang, Q.; Menad, N.; Lidstrom Larsson, M.; Bjorkman, B. Characteristics of steel slag under different cooling conditions. Waste Manag. 2007, 27, 1335-1344. [CrossRef] [PubMed]

44. ASTM E11-17, Standard Specification for Woven Wire Test Sieve Cloth and Test Sieves. In Book of Standards; ASTM International: West Conshohocken, PA, USA, 2017.

45. ISO. ISO 527:2012 Plastics—Determination of Tensile Properties; ISO: Geneva, Switzerland, 2006.

46. ISO. ISO 178:2019 Plastics—Determination of Flexural Properties; ISO: Geneva, Switzerland, 2019.

47. ISO. ISO 14544:2016 Fine Ceramics (Advanced Ceramics, Advanced Technical Ceramics)—Mechanical Properties of Ceramic Composites at high Temperature-Determination of Compression Properties (ISO 14544:2013); ISO: Geneva, Switzerland, 2016.

48. ISO. ISO 37 Rubber, Vulcanized or Thermoplastic_Determination of Tensile Stress-Strain Properties; ISO: Geneva, Switzerland, 2017.

49. Çoruh, S.; Elevli, S.; Ergun, O.N.; Demir, G. Assessment of leaching characteristics of heavy metals from industrial leach waste. Int. J. Miner. Process. 2013, 123, 165-171. [CrossRef]

50. Król, A.; Mizerna, K. The effect of particle size reduction of waste material on heavy metals release. Chemik 2015, 69, 670-673.

51. Guo, Z.; Zhang, L.; Cheng, Y.; Xiao, X.; Pan, F.; Jiang, K. Effects of pH, pulp density and particle size on solubilization of metals from a $\mathrm{Pb} / \mathrm{Zn}$ smelting slag using indigenous moderate thermophilic bacteria. Hydrometallurgy 2010, 104, 25-31. [CrossRef]

52. ISO. ISO 48 Rubber, Vulcanized or Thermoplastic_Determination of Hardness_Part 4: Indentation Hardness by Durometer Method (Shore Hardness); ISO: Geneva, Switzerland, 2018.

53. Broitman, E. Indentation hardness measurements at macro-, micro-, and nanoscale: A critical overview. Tribol. Lett. 2017, 65, 1-18 [CrossRef]

54. Dannhauser, W. Polymeric materials (Winding, Charles, C.; Hiatt, Gordon, D.). J. Chem. Educ. 1962, 39. [CrossRef]

55. Pegoretti, A.; Dorigato, A. Polymer composites: Reinforcing fillers. In Encyclopedia of Polymer Science and Technology; John and Wiley and Sons: Hoboken, NJ, USA, 2019.

56. Leong, Y.W.; Abu Bakar, M.B.; Ishak, Z.A.M.; Ariffin, A.; Pukanszky, B. Comparison of the mechanical properties and interfacial interactions between talc, kaolin, and calcium carbonate filled polypropylene composites. J. Appl. Polym. Sci. 2004, 91, 3315-3326. [CrossRef]

57. Nurdina, A.K.; Mariatti, M.; Samayamutthirian, P. Effect of filler surface treatment on mechanical properties and thermal properties of single and hybrid filler-filled PP composites. J. Appl. Polym. Sci. 2011, 120, 857-865. [CrossRef]

58. Liang, J.-Z.; Ruan, J.-Q.; Li, B. Effects of the surface treatment of wollastonite on the tensile and flow properties for reinforced polypropylene composites. J. Polym. Eng. 2014, 34, 649-655. [CrossRef]

59. Pukánszky, B. Influence of interface interaction on the ultimate tensile properties of polymer composites. Composites $\mathbf{1 9 9 0}$ 21, 255-262. [CrossRef]

60. Švehlová, V.; Polouček, E. Mechanical properties of talc-filled polypropylene. Influence of filler content, filler particle size and quality of dispersion. Die Angew. Makromol. Chem. 1994, 214, 91-99. [CrossRef]

61. Budiyantoro, C.; Sosiati, H.; Kamiel, B.P.; Fikri, M.L.S. The effect of $\mathrm{CaCO}_{3}$ filler component on mechanical properties of polypropylene. In Proceedings of the IOP Conference Series: Materials Science and Engineering, Yogyakarta, Indonesia, 8-12 October 2018; Volume 432.

62. Roland, C.M. Reinforcement of elastomers. Ref. Modul. Mater. Sci. Mater. Eng. 2016. [CrossRef]

63. Wang, Q.; Yang, F.; Yang, Q.; Chen, J.; Guan, H. Study on mechanical properties of nano-Fe3O4 reinforced nitrile butadiene rubber. Mater. Des. 2010. [CrossRef]

64. Wang, Q.; Yang, F.; Yang, Q.; Guan, H.; Chen, J.; Zhao, B. Study on magnetic and physical mechanical properties of NBR composites filled with nano-Sro $6 \mathrm{Fe}_{2} \mathrm{O}_{3}$. J. Elastomers Plast. 2011. [CrossRef]

65. Teh, P.L.; Mariatti, M.; Akil, H.M.; Yeoh, C.K.; Seetharamu, K.N.; Wagiman, A.N.R.; Beh, K.S. The properties of epoxy resin coated silica fillers composites. Mater. Lett. 2007, 61. [CrossRef]

66. European Parliament; Council of the European Union Directive 2000/53/EC of the European Parliament and of the Council of 18 September 2000 on end-of life vehicles-Commission Statements. Off. J. Eur. Union 2000, 269, 56-70. 